原著

\title{
破裂細菌性脳動脈瘤の治療
}

\author{
河本 俊介, 堤一生, 永田 和战 \\ 染川堅, 吉河学史
}

\section{Treatment of Ruptured Intracranial Infective Aneurysm}

\author{
Shunsuke Kawamoto, M.D., Kazuo Tsutsumi, M.D., Kazuya NaGata, M.D., \\ Ken Somekawa, M.D., and Gakushi Yoshikawa, M.D. \\ Department of Neurosurgery, Showa General Hospital, Tokyo, Japan
}

\begin{abstract}
Summary: Ruptured intracranial infective aneurysms are well-known but relatively uncommon. During the past 7 years, we treated 7 cases of angiographically verified, ruptured infective aneurysms. They comprised $1.8 \%$ of all the ruptured intracranial aneurysms treated at our institution during the same period. The incidence of ruptured mycotic aneurysm among patients with active infective endocarditis was $13.0 \%$ (7 out of 54). Five patients presented with intracerebral hemorrhage, and 2 with pure acute subdural hematoma. Five aneurysms (71.4\%) were located on the distal branch of the middle cerebral artery, and $2(28.6 \%)$ on the distal branch of posterior cerebral artery. Four of the 7 aneurysms (57.1\%) were located in the "watershed" area between middle and posterior cerebral arteries.

Two patients who presented with acute subdural hematoma were in a life-threatening condition and required emergency surgery; 1 patient showed rapid clinical deterioration due to repeated rebleeding from the aneurysm. Among the 5 patients who presented with intracerebral hemorrhage, 1 underwent evacuation of hematoma and excision of the aneurysms, 2 underwent conservative treatment with antibiotics, and the other 2 were too critically ill to be treated. The infective organism could be identified in 4 of the treated 5 cases; penicillin G was given in 4 patients and cefcapene in one. All 5 treated patients returned to normal life. Ruptured intracranial infective aneurysm should be excised as soon as possible because rebleeding from the aneurysm can cause rapid clinical deterioration.
\end{abstract}

\author{
Key words: \\ - mycotic aneurysm \\ - infective aneurysm \\ - ruptured aneurysm \\ - treatment \\ - infective endocarditis
}

Surg Cereb Stroke

(Jpn) 31: 111-116, 2003

\section{はじめに}

細菌性動脈瘤はよく知られた疾患概念であるが, 実際に 臨床で遭遇することは比較的まれであり，報告例もまとま ったものが少ない8)10)22》ため, いざ患者が発生すると, 治療方針につき戸惑う場合がある。今回われわれは，過去
7 年間に当施設(:次救命救急センターを併設)で経験した 例をまとめ，統計を呈示するとともに，診断上の注意点， および治療方針につき考察する。

\section{対象および統計}

1995 年 1 月から 2001 年 12 月までの 7 年間に当施設で経

公立昭和病院 脳神経外科(受稿日 2002. 8.19)〔連絡先： $=321-0293$ 枋木県下都賀郡壬生町北小林 880 獨協医科大学 脳神経外科 河 本俊介] [Mailing address: Shunsuke Kawamoto, M.D., Department of Neurosurgery, Dokkyo University School of Medicine, 880 Mibu, Tochighi 321-0293, Japan] 
験した破裂細菌性動眽瘤の例は 7 例で，同じ期間内に当院 で治療した破裂脳動脈瘤 $(\mathrm{n}=390)$ の $18 \%$ であった。練菌 性動脈瘤の診断は, 活動性の感染性心内膜炎の存在下に, 脳動脈末梢部の動脈瘤が脳血管撮影にて証明された場合に 確定とし，これに加えて手術例では組織学的に動脈壁の感 染性炎症所見を証明した。

症例の内䚿を Table 1 に示寸. 男女比は男性 5 例・文性 2 例で, 年齢は 23-73 歳(平均 42 歳)であった。発症様式は, 脳出血(皮質下出血)が 5 例(うちくも膜下出血の合併 1 例), くも膜下出血を伴わない急性硬膜下血腫が2例であった。 動脈瘤の部位は, 中大脳動脈末梢部が 5 例 (71.4\%), 後大 脳動脈末梢が 2 例 (28.6\%)であった。合併する心升膜疾患 としては，僧帽弁閉鎖不全が最も多く，7例中 6 例に合併 がみられた(Table 1, Case 1-6).な扔Case 7 は他施設で 感染性心内膜炎の治療中に脳出血を合併して当院に搬送さ れた例であったため, 弁疾患についての詳紐は不明であっ た。

一方，同じ期間内に当院の循環器科にて診断を確定し治 療を行った感染性心内膜炎は 54 例であった。したがって， 活動性の感染性心内膜炎患者に破裂紐菌性脳動脈瘤を合併 した率は $13.0 \%$ であった。

\section{結 果}

\section{1. 出血に詨する治療}

脳出血発症例 (5例)のうち2 例(Case 6,7) は血腫が大き く, かろうじて脳血管撮影までは施行したものの, 手術に は至らなかった。2例(Case 1，4) は局所症状のみで発症し
て㧍り，保存的に治療した。1例(Case 2, Fig. 1)では局 所症状に加えて軽度の意識障害を伴って扔り，血腫除去術 および動脈瘤切除を施行した。

Case 3 およびCase 5 の2例は，いずれも life-threatening な急性硬膜下血腫で発症しており, 緊急の血腫除去術 を要した。このうち Case 3(Fig. 2)は，発症直後より急速 に進行する重篤な意識障害を呈していたため，まず緊急に て減圧開頭血腫除去術を行ったのち，脳血管撮影にて紐菌 性動脈瘤の部位を確定してすみやかに動脈瘤の切除を行っ た.Case 5 は短時間に再破裂を繰り这し治療に苦慮した 症例である。来院時 CTにて急性硬膜下血腫の主座は fronto-parietal に存在した（Fig. 3A)のに対し，動脈瘤は parieto-occipital の傍矢状洞部に位置していた (Fig. 4).2 病変の位置関停より血腫除去と動脈瘤の処理を同時に行う ことは不可能と判断し，まず緊急にて減圧開頭血腫除去術 を行い，体位を変えて動脈瘤切除を行う予定とした。しか しながら血腫除去の術直後より急性硬膜下血腫の再発を認 めた(Fig. 3B)ため, fronto-temporal の減圧部の術創を. 部再開創した状態で血腫を創外にドレナージしつつ， parieto-occipital の動脈瘤切除を行い, 最後に再度fronto temporalの血腫除去を行った (Fig. 3C)。動脈瘤の組織学 的所見では, 内弾性板の断裂，扔よび動脈壁内の a bscess を認め, 紏菌性動㟲瘤に合致する所見であった（Fig. 5)。

\section{2. 起炎菌に対する治療，および最終予後}

起炎菌は治療例 5 例中 4 例で问定された。このうち 3 例 は連鎖球菌群で(Case 1，3，5)，1例は腸球菌であった

Table 1 Clinical summary of 7 ruptured mycotic aneurysms

\begin{tabular}{|c|c|c|c|c|c|c|c|c|c|c|c|}
\hline Case & Age & Sex & Stroke type & $\begin{array}{l}\text { Neurology } \\
\text { on admission }\end{array}$ & $\begin{array}{l}\text { Site of aneurysm } \\
\text { * }\end{array}$ & treatment & Pathology & $\begin{array}{l}\text { Infecting } \\
\text { organism }\end{array}$ & Heart disease & Antibiotics & Outcome* * \\
\hline 1 & 37 & M & ICH (Lt. Frontal) & Focal & $\begin{array}{l}\text { Distal MCA } \\
\text { (pre-central) }\end{array}$ & Conservative & NA & Str. Mutans & $M R+T R$ & PCG & GR \\
\hline 2 & 40 & M & ICH (Lt. Parietal) & $\begin{array}{l}\text { E4V4M6+ } \\
\text { focal }\end{array}$ & $\begin{array}{l}\text { Distal MCA } \\
\text { (posterior-parietal) }\end{array}$ & $\begin{array}{l}\text { Evacuation \& } \\
\text { excision }\end{array}$ & $\begin{array}{l}\text { Mycotic } \\
\text { aneurysm }\end{array}$ & No growth & MR & PCG & GR \\
\hline 3 & 23 & M & Pure ASDH & ElVIMI & $\begin{array}{l}\text { Distal MCA } \\
\text { (angular) }\end{array}$ & $\begin{array}{l}\text { Evacuation \& } \\
\text { excision }\end{array}$ & $\begin{array}{l}\text { Mycotic } \\
\text { aneurysm }\end{array}$ & $\alpha$-hemolytic str. & MR & PCG & GR \\
\hline 4 & 57 & $\mathrm{~F}$ & $\begin{array}{l}\text { ICH (Rt. } \\
\text { Occipital) }\end{array}$ & Focal & $\begin{array}{l}\text { Distal PCA } \\
\text { (parieto-occipital) }\end{array}$ & Conservative & NA & Ent. Faecalis & $M R+A R$ & cefcapene & $G R$ \\
\hline 5 & 40 & M & Pure ASDH & EIVIMI & $\begin{array}{l}\text { Distal PCA } \\
\text { (parieto-occipital) }\end{array}$ & $\begin{array}{l}\text { Evacuation \& } \\
\text { excision }\end{array}$ & $\begin{array}{l}\text { Mycotic } \\
\text { aneurysm }\end{array}$ & Str. viridance & MR & PCG & GR \\
\hline 6 & 73 & $\mathrm{~F}$ & $\begin{array}{l}\mathrm{ICH} \text { (Lt. } \\
\text { Fronto-parietal) }\end{array}$ & EIVIMI & $\begin{array}{l}\text { Distal MCA } \\
\text { (central) }\end{array}$ & None & NA & NA & $M R+A S D$ & none & D \\
\hline 7 & 27 & M & ICH (Lt. frontal) & EIVIMI & $\begin{array}{l}\text { Distal MCA } \\
\text { (pre-central) }\end{array}$ & None & NA & NA & $\begin{array}{l}\text { Unknown (IE } \\
\text { treated at another } \\
\text { institution) }\end{array}$ & none & D \\
\hline
\end{tabular}

*Glasgow Coma Scale; * *Glasgow Outcome Scale; NA, not available; Str., streptococcus; Ent., enterococcus; MR, mitral regurgitation; TR, tricuspid regurgitation; $A R$, aortic regurgitation; $A S D$, atrial septal defect; $I E$, infective endocarditis; $P C G$, penicillin $G$ 

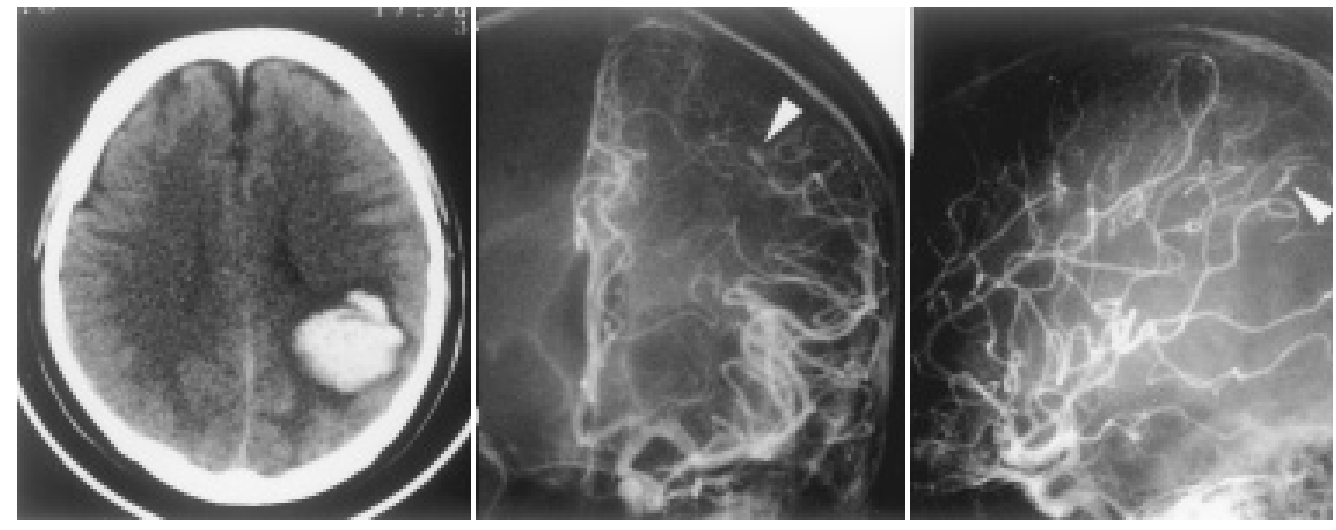

Fig. 1 Neuro-imaging of Case 2. A: CT scan on admission showing a left parietal subcortical hematoma. B, C: AP (B) and lateral $(\mathbf{C})$ left carotid angiogram depicting the mycotic aneurysm (arrowheads) on a branch of the left posterior-parietal artery.
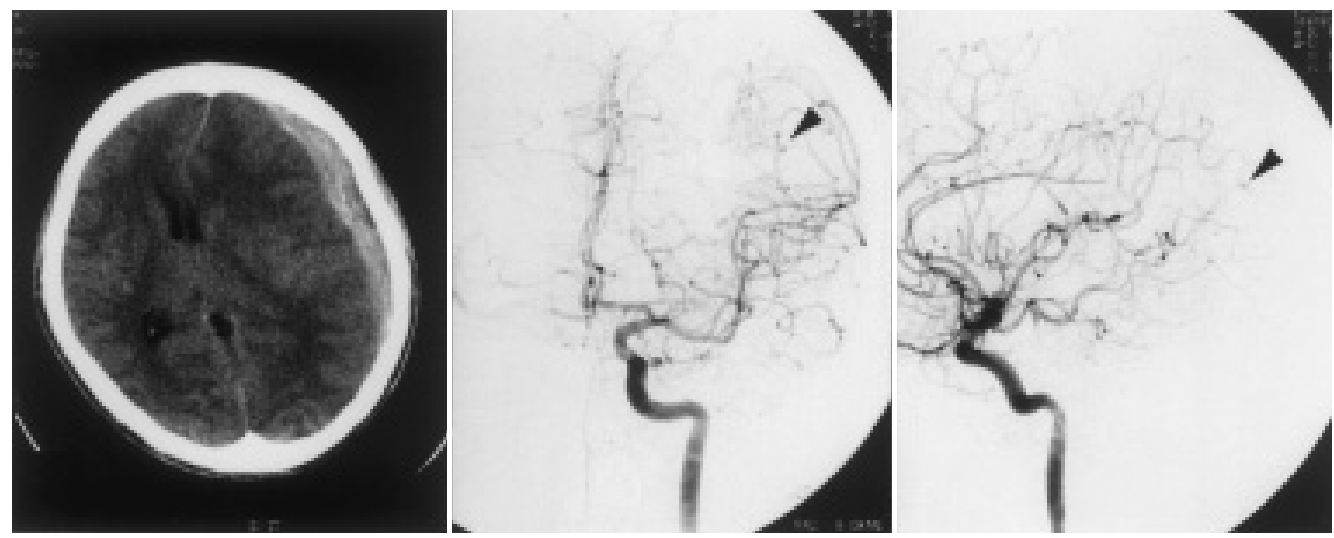

Fig. 2 Neuro-imaging of Case 3. A: CT scan on admission showing an acute left fronto-parietal subdural hematoma with midline shift. B, C: AP (B) and lateral $(\mathbf{C})$ left carotid angiogram depicting the mycotic aneurysm (arrowheads) on a distal branch of the left angular artery.
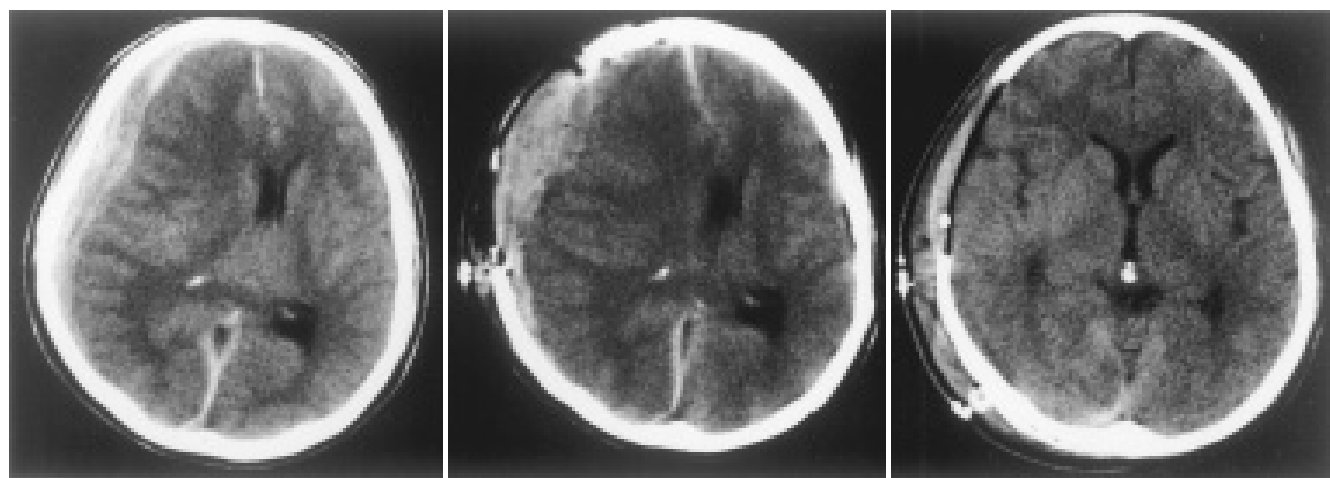

Fig. 3 Serial CT scans of Case 5. A: Preoperative CT scan showing an acute right fronto-parietal subdural hematoma with midline shift. B: CT scan immediately after decompressive craniectomy depicting re-accumulation of acute subdural hematoma with midline shift. C Postoperative CT scan demonstrating satisfactory evacuation of the subdural hematoma. 


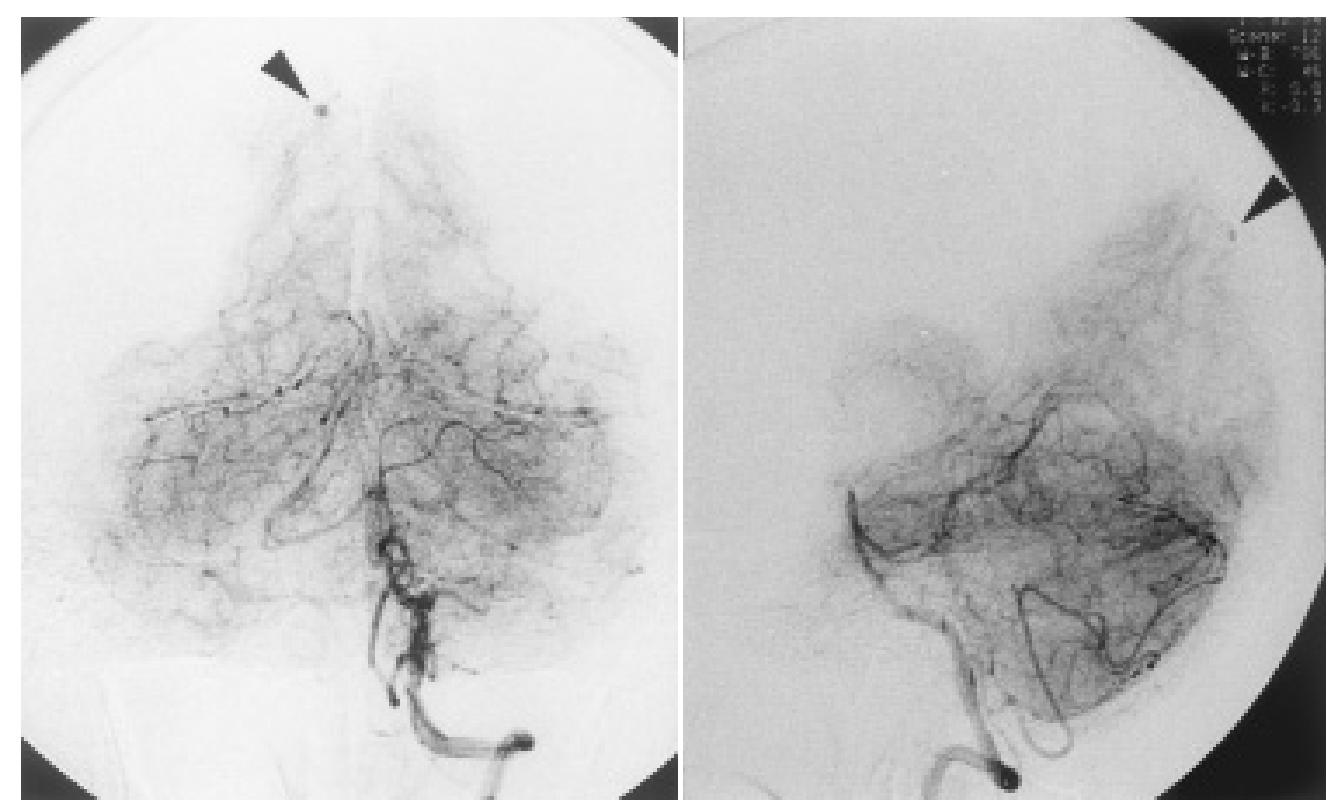

Fig. 4 Angiogram of Case 5. AP $(\mathbf{A})$ and lateral (B) left vertebral angiogram showing the mycotic aneurysm on a distal branch of the right parieto-occipital artery in the vicinity of parasagit- $\mathbf{A} \mid \mathbf{B}$ tal area (arrowheads).

(Case 4)。連鎖球菌群が同定された 3 例，および菌が司定 されなかった 1 例(Case 2)に対して penicillin Gを投与し (Case 2については putative treatment)，また腸球菌が司 定されたCase 4 に対しては cefcapeneを投与して，いず れも治癒した。これら治療例 5 例は全例神経学的欠落症状 なしに社会復帚した。

\section{考察}

細菌性脳動脈瘤は脳動脈瘤全体の $2.6^{-4} 4 \%$ を占めると され ${ }^{10) 23\rangle}$, 比較的まれながら教科書的にはよく知られた 疾患概念であるが, 実際に臨床で破裂例に遭遇することは, Chunらも述べているように非常に少ない8).われわれの 施設でも，同時期に経験した破裂脳動脈瘤のうち $1.8 \%$ と きわめてまれであった，基礎疾患として重岀なのは感染性 心内膜炎であり，感染性心内膜炎患者の 4-15\%に紐菌性 脳動脈瘤を合併するとされる ${ }^{522}$ 。われわれの施設でも活 動性感染性心内膜炎患者の $13.0 \%$ に破裂細菌性脳動脈瘤を 合併して扔り，感染性心内膜炎患者に頭蓋内出血をみた場 合には，破裂練菌性脳動脈瘤の可能性を必ず念頭に置かな ければならない。

破裂練菌性脳動脤瘤の発症様式としてはくも膜下出血な いしは脳内出血が多いとされているが57710)11)15)22)，ま れな発症様式として，自験例で 2 例みられたように急性硬 膜下血腫にて発症した例の報告も散見される ${ }^{2 \nmid 3) 16) 27)}$. 脳 動脈瘤が純䊉な急性硬膜下血腫で発症することは非常にま

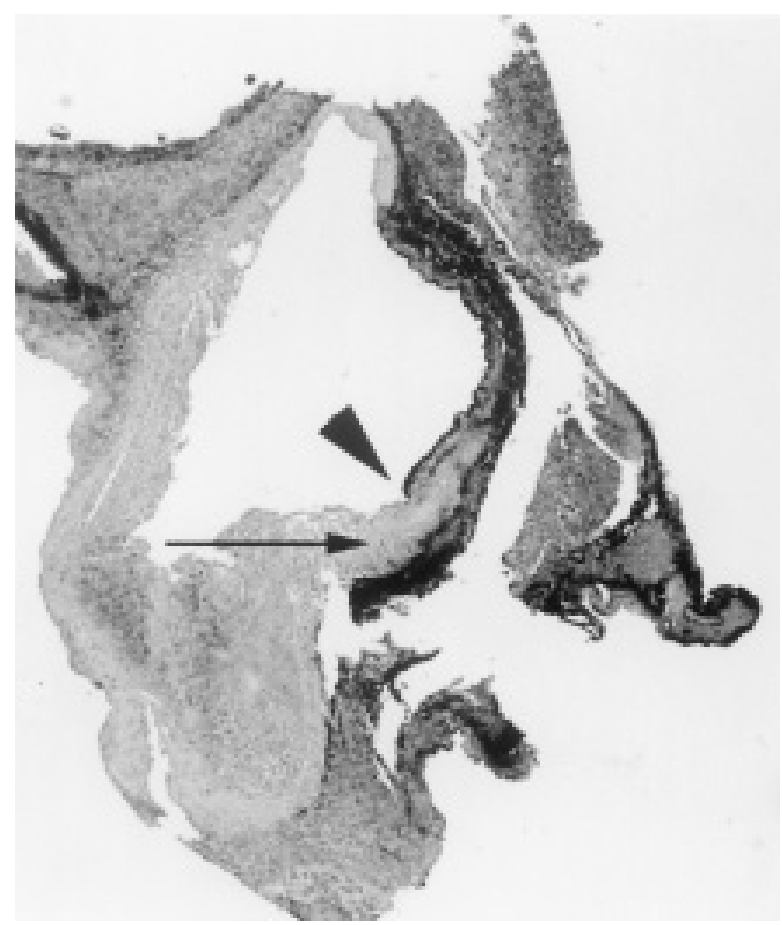

Fig. 5 Histopathological examination of the resected aneurysm demonstrating interruption of internal elastic lamina (arrowhead) and intramural abscess (arrow). elastica van Gieson, × 10. 
れとされており，くも膜下出血で発症した破裂脳動脈瘤と 比較して重症例が多いとされている ${ }^{21)}$. Baramiらは，な かでも破裂紐菌性脳動脈瘤による急性硬膜下血腫のほうが 通常の褰状動脈瘤の破裂によるものよりも予後が患心 と述ベているが，これは自験例 2 例およびその他の報告例 についてもあてはまり六27)，後述するように動脈瘤壁が脆 弱であるために容易に再破裂をきたすことによると推測さ れる。

細菌性脳動脈瘤の発生部位は, 中大脳動脤の未梢部が最 も多く，75-80\%がこの部位に発生するとされる ${ }^{10) 22) . 今 ~}$ 回検討した症例でも，7例中 5 例 $(71.4 \%)$ が中大脳動脈の 末梢であった。方，部位でみると， 7 例中 4 例 $(57.1 \%$, Case 2,3,4,5)が頭頂葉後端部から後頭葉にかけての領域, 子なわち中大脳動脈から後大脳動脈にかけての watershed areaの末梢部に発生していることが特徽的であった。こ のことは，診断において，脳血管撮影を検討するうえで注 意す心゙き点と思われる.とくに, Case 5(Fig. 3,4)のよう) にfronto-temporal の急性硬膜下血腫で発症していながら 動脈瘤が後大脳動脤末梢部に存在する場合もあり, 脳血管 撮影の検討には十分な注意が必要である。

細菌性脳動脈瘤の治療方針としては, 内科的治療, 外科 的切除, 血管内手術など種々の方法が報告されているが

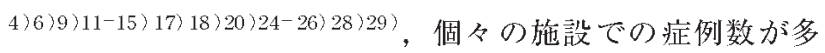
くないために，基準となる治療方針が確立されるに至って いないのが現状である。このうち破裂したものに関しては， mass effectを伴う血腫を呈する場合には血腫除去が必要 なことはいうまでもないが5) 8), 症状が軽い場合, 動脈瘤 切除にまで踏み切るのは躊躇される場合がある。実際, わ れわれの経験した例でも, 脳内血腫で発症したもののうち 2 例 (Case 1, 4) は抗生剂投与のみで治療して良好な結果を 得た。

・方で, Case 5 のように再破裂を繰り返して治療に難 渋する例もある。組織病理学的所見上, 内弾性板の断裂, 動脈瘤㧍よび周辺の動脤の壁の壞死 ${ }^{2)}$, 血管壁の壁内膿瘍 (Fig. 5)を認める点は, 仮性動脈瘤としての特徵を示して 拐り，動脈瘤壁が炎症で脆弱になっているために特に再破 裂をきたしやすいと考えられる。したがって破裂細菌性脳 動脈瘤の自然経過は, 椎骨動脈解離性動脤瘤のそれ ${ }^{19}$ に 類似していると考えるべきであり，再破裂を繰り这すこと を前提として治療にあたる必要がある、脳表に位置する䋱 菌性動脈瘤が破裂して硬膜下血腫をきたすことはまれであ るが,この場合にはとくに，脳内血腫と比べると局所の血 腫による圧迫止血機序が働きにくく，われわれのCase 3 , 5 や報告例 ${ }^{23}$ 27)にみられるように, 重症化しやすく,ま たとくに再破裂も起こしやすいといえる。

以上のことを考えると, 破裂紐菌性脳動脈瘤は,
Frazeeや Bohmfalkらの述べるように 腫があればこれを除去したうえで，動脈瘤そのものに対し ても可及的すみやかに切除することを原則とするべきであ ると考えられる。

なお，われわれの経験した例では，動脈瘤はすべて中大 脳動脈あるいは後大脳動脈の最も末悄部に位置しており， 動脈瘤切除に際して血行再建術を必要とする例はなかった が，動㟲瘤がこれよりも中枢侧に位置する場合には，同時 に血行再建術を行うことも考慮するべきである ${ }^{8)}$.

\section{まとめ}

当院で経験した破裂細菌性動脈瘤について報告した。診 断上, 中大脳動脈から後大脳動脤にかけての watershed areaの末梢部につき注意して観察する必岀がある。治療 では，動㟲瘤自体を可及的すみやかに切除することが望ま しい.

最後に本論文の要旨は第 31 回П本脳卒中の外科学会 (2002年，仙台)で発表した。

\section{文献}

1) Anguita $\mathrm{M}$, Romo $\mathrm{E}, \mathrm{V}$ inals $\mathrm{M}$, et al: The management by medical treatment of an intracranial mycotic aneurysm in a patient with infectious endocarditis with negative blood cultures and hy pertrophic myocardiopathy. Rev Esp Cardiol 44: 556-559, 1991

2) Bandoh K, Sugimura J, Hosaka Y, et al: Ruptured intracranial mycotic aneurysm associated with acute subdural hematoma: case report. Neurol Med Chir (Tokyo) 27: 56-59, 1987

3) Barami K, Ko K: Ruptured mycotic aneurysm presenting as an intraparenchymal hemorrhage and nonadjacent acute subdural hematoma: case report and review of the literature. Surg Neurol 41: 290-293, 1994

4) Bingham WF: Treatment of mycotic intracranial aneurysms J Neurosurg 46: 428-437, 1977

5) Bohmfalk GL, Story JL, Wissinger JP, et al: Treatment of mycotic aneurysms. J Neurosurg 54: 566-567, 1981

6) Bolender NF, Bassett MR, Loeser JD, et al: Mycotic aneurysm of the internal carotid artery. A surgical emergency. Ann Otol Rhinol Laryngol 93: 273-276, 1984

7) Brust JC, Dickinson PC, Hughes JE, et al: The diagnosis and treatment of cerebral mycotic aneurysms. Ann Neurol 27: $238-246,1990$

8) Chun JY, Smith W, Halbach VV, et al: Current multimodality management of infectious intracranial aneurysms Neurosurgery 48: 1203-1213, 2001

9) Cloft HJ, Kallmes DF, Jensen ME, et al: Endovascular treatment of ruptured, peripheral cerebral aneurysms: parent artery occlusion with short Guglielmi detachable coils. AJNR Am J Neuroradiol 20: 308-310, 1999

10) Frazee JG, Leslie DC, Winter J: Bacterial intracranial aneurysms J Neurosurg 53: 633-641, 1980

11) Frizzell RT, Vitek JJ, Hill DL, et al: Treatment of a bac- 
terial (mycotic) intracranial aneurysm using an endovascular approach. Neurosurgery 32: 852-854, 1993

12）金谷憲明，佐藤公一，古明地孝宏，ほ力：感染性心内膜炎 手術後に発生した mycotic cerebral aneurysm 91 症例. 麻 醉 42: $1359-1362 ， 1993$

13）片倉康喜, 嘉山孝正, 近藤礼, ほか：血管内手術によっ て治療した多発性細菌性脳動脈瘤の1 例. 脳外 23: 11271132, 1995

14）川上圭太, 嘉山孝正, 近藤 礼, ほか：血管内于術にて処 置し得た mycotic ICA petrous portion aneurysmの 1 例. 脳外 24: 253-257, 1996

15) Khayata MH, Aymard A, Casasco A, et al: Selective endovascular techniques in the treatment of cerebral mycotic aneurysms Report of three cases. J Neurosurg 78 : $661^{-665,} 1993$

16) King AB: Successful surgical treatment of an intracranial mycotic aneurysm complicated by a subdural hematoma. J Neurosurg 17: 788-791, 1960

17) Kuki S, Yoshida K, Suzuki K, et al: Successful surgical management for multiple cerebral mycotic aneurysms involving both carotid and vertebrobasilar systems in active infective endocarditis. Eur J Cardiothorac Surg 8: 508-510, 1994

18) Leipzig TJ, Brown FD: Treatment of mycotic aneurysms. Surg Neurol 23: 403-407, 1985

19) Mizutani $T$, Aruga $T$, Kirino $T$, et al: Recurrent subarachnoid hemorrhage from untreated ruptured vertebrobasilar dissecting aneurysms. Neurosurgery 36: 905-913, 1995

20) Monsuez JJ, Vittecoq D, Rosenbaum A, et al: Prognosis of ruptured intracranial mycotic aneurysms: a review of
12 cases. Eur Heart J 10: 821-825, 1989

21) Nonaka $\mathrm{Y}$, Kusumoto $\mathrm{M}$, Mori $\mathrm{K}$, et al: Pure acute subdural haematoma without subarachnoid haemorrhage caused by rupture of internal carotid artery aneurysm. Acta Neurochir (Wien) 142: 941-944, 2000

22) Ojemann RG: Surgical management of bacterial intracranial aneurysms, in: Schmidek HH, Sweet WH (eds): Operative Neurosurgical Techniques, Indications, Methods, and Results. New York, Grune \& Stratton, 1982, pp933- 940

23) Roach MR, Drake CG: Ruptured cerebral aneurysms caused by micro-organisms. $N$ Engl J Med 273: 240-244, 1965

24）佐々木進次郎，麻田邦夫，小土解宏，ほ浪：感染性心内膜 炎に対要る外科的治療の経験. 胸部外科 47: 209-214, 1994

25) Sato T, Sakuta Y, Suzuki J, et al: Successful surgical treatment of intracranial mycotic aneurysm with brain abscess. Report of a case. Acta Neurochir (Wien) 47: 53-61, 1979

26) Terada Y, Kikawa I, Wanibuchi Y: Late rupture of a mycotic cerebral aneurysm after mitral valve replacement for bacterial endocarditis in the inactive stage. Med J Aust 159: 567,1993

27）㹃井雅弘，芦立 久：急性硬膜下血腫で発症した細菌性脳 動脈瘤と思われる末梢性脳動脈瘤の1例. 脳外 30: 177-181, 2002

28) Utoh J, Miyauchi Y, Goto H, et al: Endovascular approach for an intracranial mycotic aneurysm associated with infective endocarditis. J Thorac Cardiovasc Surg 110: 557559,1995

29) Watanabe A, Hirano $K$, Ishii $R$ : Cerebral mycotic aneurysm treated with endovascular occlusion: case report. Neurol Med Chir (Tokyo) 38: 657-660, 1998 